\title{
The use of Lactobacillus species as starter cultures for enhancing the quality of sugar cane silage
}

\author{
C. L. S. Ávila, ${ }^{\star}$ B. F. Carvalho, ${ }^{\star}$ J. C. Pinto, $†$ W. F. Duarte, ${ }^{\star}$ and R. F. Schwan ${ }^{\star 1}$ \\ *Department of Biology, and \\ †Department of Animal Science, Federal University of Lavras, 37.200-000, Lavras, Minas Gerais, Brazil
}

\begin{abstract}
Sugar cane (Saccharum spp.) is a forage crop widely used in animal feed because of its high dry matter (DM) production (25 to $40 \mathrm{t} / \mathrm{ha}$ ) and high energy concentration. The ensiling of sugar cane often incurs problems with the growth of yeasts, which leads to high losses of DM throughout the fermentative process. The selection of specific inoculants for sugar cane silage can improve the quality of the silage. The present study aimed to select strains of lactic acid bacteria (LAB) isolated from sugar cane silage and to assess their effects when used as additives on the same type of silage. The LAB strains were inoculated into sugar cane broth to evaluate their production of metabolites. The selected strains produced higher concentrations of acetic and propionic acids and resulted in better silage characteristics, such as low yeast population, lower ethanol content, and lesser DM loss. These data confirmed that facultative heterofermentative strains are not good candidates for sugar cane silage inoculation and may even worsen the quality of the silage fermentation by increasing DM losses throughout the process. Lactobacillus hilgardii strains UFLA SIL51 and UFLA SIL52 resulted in silage with the best characteristics in relation to DM loss, low ethanol content, higher LAB population, and low butyric acid content. Strains UFLA SIL51 and SIL52 are recommended as starter cultures for sugar cane silage.
\end{abstract} Key words: inoculant, Lactobacillus hilgardii, 1,2-propanediol, yeast

\section{INTRODUCTION}

The ensiling process may occur either naturally, with epiphytic microorganisms present on the plant material, or with the addition of inoculants to improve the process, thus resulting in better quality silage. Microbial inoculants are commercially available for use in silage, and lactic acid bacteria $(\mathbf{L A B})$ are the main

Received May 1, 2013.

Accepted November 2, 2013.

${ }^{1}$ Corresponding author: rschwan@dbi.ufla.br microorganisms used for this purpose (Cai et al., 1999; Driehuis et al., 2001; Filya, 2003).

In general, studies with LAB inoculants show that inoculation before ensiling increases the fermentation quality of the ensiled forage (Kleinschmit and Kung, 2006; Zopollatto et al., 2009). However, the results can be inconsistent when forage crops are evaluated under different conditions, such as silo size, climate, and packing density. Factors related to the storage and application of inoculants might influence their effects on silage quality. Nevertheless, one of the determining factors for the successful application of microbial inoculants in silage is the compatibility between the plant and the microorganisms used (Muck, 2008; Ávila et al., 2009). This compatibility can be assessed by the ability of the microorganisms to use carbohydrates present in the forage and to produce metabolites of interest, primarily in the preservation of silage (e.g., acetic and lactic acids).

Sugar cane (Saccharum spp.) is a forage crop widely used in animal feed because of its high DM production ( 25 to $40 \mathrm{t} / \mathrm{ha}$ ) and high energy concentration, which is due to the high concentration of sugars, mainly sucrose (250 to $300 \mathrm{~g} / \mathrm{kg}$ ). The ensiling of sugar cane often results in problems with the overgrowth of yeasts, which leads to high losses of DM throughout the fermentative process (Kung and Stanley, 1982). Chemical and microbiological additives have been tested with the aim of reducing yeast growth. However, microbial inoculants have produced better results than chemical additives (Carvalho et al., 2012).

Inoculants with LAB, which produce higher concentrations of acetic or propionic acids, are more suitable for yeast control because of the fungicidal effect of these acids (Moon, 1983). The addition of microorganisms that produce greater amounts of lactic acid are of interest because of their rapid effect in reducing the $\mathrm{pH}$ value. However, lactic acid is a potential substrate for yeast during feeding-out, reducing the aerobic stability of the silage. Inoculation with facultative heterofermentative Lactobacillus plantarum and obligatory heterofermentative Lactobacillus buchneri has been tested during ensiling of sugar cane. The results are variable, but in general, Lb. buchneri showed good results in reducing 
the DM losses and increased aerobic stability (Ávila et al., 2009; Roth et al., 2010). Pedroso et al. (2008) observed that $L b$. buchneri improved fermentative and aerobic stability in silages, whereas $L b$. plantarum strains interfered negatively in the fermentation and preservation of sugar cane silages. Ávila et al. (2010b) evaluated different LAB species ( $L b$. plantarum, Lactobacillus paracasei, Lactobacillus brevis, and Lactobacillus brevis buchneri) and observed that the effect of the inoculant is more related to the strain used than to the species. Inoculations with different strains that belong to the same species have resulted in silages with different characteristics, suggesting that studies should be conducted not only at the species level but also at the strain level (Saarisalo et al., 2007; Ávila et al., 2011).

The effects of microbial inoculants on the fermentation process of silage are mainly due to the production of metabolites of interest able to inhibit the growth of undesired microorganisms. Therefore, the ability of a strain to utilize different substrates present in the forage plant and to produce different metabolites can be an advantage in the competition with other microorganisms. This ability can be used as a criterion for selecting inoculants (Saarisalo et al., 2007). The present study aimed to isolate, identify, and select LAB strains for the ensiling of sugar cane by a rapid method based on the production of metabolites that are relevant for the silage process. In addition to strain performance, we evaluated the improvement of chemical and microbiological silage characteristics in experimental silos.

\section{MATERIALS AND METHODS}

\section{Experiment 1: Isolation and Characterization of LAB from Sugar Cane Silage}

Silages were made with fresh-cut sugar cane from plants that were approximately 12 mo old. The sugar cane was manually harvested and chopped using a laboratory-type chopper (PP-47, Pinheiro, Itapira, SP, Brazil) at an approximate length of $30 \mathrm{~mm}$. Approximately $10 \mathrm{~kg}$ of chopped material was immediately conditioned in 15 -L plastic buckets without valves for gas release or effluent (mini-silos). The material was compacted to a density of approximately $700 \mathrm{~kg}$ of fresh matter $/ \mathrm{m}^{3}$. The mini-silos were stored at room temperature $\left(22^{\circ} \mathrm{C}\right)$ and opened after $0,2,15,60$, and $90 \mathrm{~d}$ of storage. Samples were taken on each opening day for $\mathrm{pH}$ analysis. Two replicates were prepared for each date of sampling.

The LAB were isolated from $80 \mathrm{~g}$ of sugar cane silage that was mixed with $720 \mathrm{~mL}$ of $0.1 \%$ sterile peptone water and homogenized in an orbital mixer for 20 min. Subsequently, 10-fold dilutions were prepared to quantify the LAB using de Man, Rogosa, and Sharpe agar (MRS, Difco, Detroit, MI) containing $0.1 \%$ cysteine- $\mathrm{HCl}$ and cycloheximide (0.4\%). The plates were incubated at $30^{\circ} \mathrm{C}$ for $48 \mathrm{~h}$ under anaerobic conditions (Gas Pack Anaerobic System, BBL, Cockeysville, MD). Colonies were counted on plates with 30 to 300 well-isolated cfu, and a number of colony-forming units corresponding to the square root of the total was taken at random for identification (Holt et al., 1994). The isolates were further purified by streaking individual colonies onto MRS agar. The purified isolates were maintained at $-80^{\circ} \mathrm{C}$ in MRS broth containing $20 \%$ (vol/vol) glycerol.

The size, shape, color, height, and edge morphology of each colony were noted. The presumptive lactobacilli were counted on MRS agar. The isolates were examined by Gram stain and for colony and cell appearance, catalase activity, motility and production of $\mathrm{CO}_{2}$ from glucose, and gluconate in MRS broth with a Durham tube. The lactobacilli were recognized as gram-positive, catalase-negative, oxidase-negative, regular fermentative rods, and were classified as homofermentative or heterofermentative lactobacilli by their ability to produce $\mathrm{CO}_{2}$ from glucose and gluconate.

Preselection of Bacterial Strains Based on Metabolite Production in Sugar Cane Broth. Fifty-seven isolates classified as LAB were isolated from sugar cane silage and evaluated for metabolite production. The LAB were evaluated in a $5^{\circ}$ Brix sugar cane broth medium supplemented with $0.1 \%$ yeast extract. The Brix degree (soluble solids) was determined according to AOAC (1990) using a digital refractometer Atago PR-32 (Atago USA Inc., Bellevue, WA), with automatic temperature compensation. The broth was filtered (gauze) and sterilized $\left(120^{\circ} \mathrm{C}, 15 \mathrm{~min}\right)$. First, the 57 strains were cultivated in MRS broth for $24 \mathrm{~h}$ at $35^{\circ} \mathrm{C}$. After this period, the inoculum was standardized using a spectrophotometer $(600 \mathrm{~nm})$ at an optical density of 1.0. Subsequently, approximately $400 \mu \mathrm{L}$ of each strain was inoculated into $300 \mathrm{~mL}$ of sugar cane broth, which was incubated at $35^{\circ} \mathrm{C}$ and $120 \mathrm{rpm}$. After $24 \mathrm{~h}$ of fermentation, samples of the cultures were taken to evaluate metabolite production by HPLC.

Data regarding the production of metabolites by strains were analyzed using principal component analysis (PCA). Sugar cane has a high concentration of soluble carbohydrates, a low buffering capacity, and DM content suitable for ensiling. Therefore, a decrease in pH occurs quickly (Kung and Stanley, 1982; Ávila et al., 2009). However, the overgrowth of yeast in sugar cane silage throughout the process causes DM losses (Kung and Stanley, 1982). Moreover, problems with deterioration after silo opening are common because of the high concentration of lactic acid, which serves as a 
substrate for yeast (McDonald et al., 1991). Therefore, inoculants with bacteria that are able to produce the highest concentrations of acetic or propionic acids are preferred. Consequently, for our studies in laboratory silos, the 5 best LAB strains were chosen based on their ability to produce each one of these acids. Because lactic acid is primarily responsible for the decrease in $\mathrm{pH}$ values in silage, the 4 best lactic acid-producing strains were also chosen for the tests in the experimental silos.

Molecular Identification of Selected Bacterial Strains. The strains selected for evaluation in the experimental silos were identified by DNA sequencing. The bacterial cultures were grown under appropriate conditions on MRS agar plates, and single colonies were collected with a sterile pipette tip and resuspended in $40 \mu \mathrm{L}$ of PCR buffer. The suspension was heated for $10 \mathrm{~min}$ at $95^{\circ} \mathrm{C}$, and $2 \mu \mathrm{L}$ of the suspension was used as the DNA template to amplify the full-length $16 \mathrm{~S}$ region by PCR. The approximately 1,500-bp fragment of the $16 \mathrm{~S}$ rDNA was amplified using forward primer 27f (5'AGAGTTTGATCCTGGCTCAG 3') and reverse primer 1512r (5'ACGGCTACCTTGTTACGACT $3^{\prime}$ ) (Devereux and Wilkinson, 2004). The unpurified PCR products were sequenced using an ABI3730 XL automatic DNA sequencer (Applied Biosystems, Carlsbad, $\mathrm{CA}$ ). The sequences were then compared with the GenBank database using the BLAST algorithm (http:// blast.ncbi.nlm.nih.gov/Blast.cgi; National Center for Biotechnology Information, Bethesda, MD).

\section{Experiment 2: Evaluation of Strains in Experimental Silos}

Silage was made with fresh-cut sugar cane from plants that were approximately 12 mo old. The sugar cane was manually harvested and chopped using a laboratory-type chopper (model PP-47, Pinheiro) to an approximate length of $30 \mathrm{~mm}$. Three kilograms of the chopped material was mixed with the inoculants and conditioned in polyvinyl chloride (PVC) plastic buckets (mini-silos, $10 \mathrm{~cm}$ in diameter and $60 \mathrm{~cm}$ in length), which were sealed with tight lids containing Bunsen valves for gas release. The material in the silo was compacted to a density of approximately $630 \pm 19.9 \mathrm{~kg}$ of fresh matter $/ \mathrm{m}^{3}$. The mini-silos were stored at room temperature $\left(22^{\circ} \mathrm{C}\right)$ and analyzed after $61 \mathrm{~d}$ of storage; 3 replicates were prepared for each silo.

Silage was produced using 14 selected LAB strains from the first experiment as inoculants. Silage without any inoculant was used as control. The inoculants were cultured according to Ávila et al. (2009). After the final culture, the number of cells was counted on MRS agar (CM361, Oxoid, Basingstoke, UK), and the concentration of the culture was adjusted to $9 \log \mathrm{cfu} / \mathrm{mL}$. The culture was mixed with $80 \mathrm{~mL}$ of sterile distilled water and sprayed onto the chopped sugar cane to achieve a final concentration of $6 \mathrm{log} \mathrm{cfu} / \mathrm{g}$ of herbage. The control received the same amount of water without any bacteria. A separate sprayer was used for each treatment to avoid cross-contamination.

The weights of the empty and full silos were recorded. After sealing, the silos were maintained at room temperature (average of $25^{\circ} \mathrm{C}$ ) and protected from sunlight and rain. After $61 \mathrm{~d}$ of ensiling, the full silos were weighed before opening. The loss of DM was calculated using the weight and DM content of the fresh forage and silage.

Analytical Procedures. At the moment of ensiling and on the opening day, 2 samples were removed from fresh forage and each mini-silo, and all of the contents of the mini-silos were homogenized. One of the samples was weighed and dried in a fan-assisted oven at $55^{\circ} \mathrm{C}$ for $96 \mathrm{~h}$. Another sample was used to make a water extract to determine the $\mathrm{pH}$ value, evaluate the microbial population, and detect fermentation end products.

The dried samples were ground in a Wiley-type grinder using a 1-mm sieve and stored in labeled plastic pots. The samples were analyzed for DM content (AOAC, 1990), water-soluble carbohydrates by the phenol method (Dubois et al., 1956), and NDF as described by Holden (1999), using an Ankom Fiber Analyzer (Ankom Technology Corporation, Fairport, NY) and expressed on a DM basis.

The levels of ethanol, 1,2-propanediol and lactic, acetic, propionic, and butyric acids were measured by HPLC according to Carvalho et al. (2012). The acids, ethanol, and 1,2-propanediol were identified by comparing their retention times with those of known standards. The concentrations of the identified compounds were determined by the external calibration method. The HPLC apparatus (model LC-10Ai, Shimadzu Corp., Tokyo, Japan) was equipped with a dual detection system consisting of a UV detector (UV-Vis SPD-10Ai) and a refractive index detector (RID 10A). An ion exclusion column from Shimadzu (Shim-pack SCR-101H; $7.9 \mathrm{~mm}$ i.d., $30 \mathrm{~cm}$ long) operated at $50^{\circ} \mathrm{C}$ was used for the chromatographic separation. The mobile phase consisted of $100 \mathrm{mM}$ perchloric acid solution with a flow rate of $0.6 \mathrm{~mL} / \mathrm{min}$. The acids were detected by UV absorbance $(210 \mathrm{~nm})$. Ethanol and 1,2-propanediol were identified using the refractive index detector. The $\mathrm{pH}$ values were measured with a potentiometer (Expandomatic Beckman SS-2, Beckman Coulter Inc., Atlanta, GA).

Microbiological Analyses. Samples (70 g) of fresh forage and sugar cane silage after $61 \mathrm{~d}$ of incubation were mixed with $630 \mathrm{~mL}$ of $0.1 \%$ sterile peptone water and stirred in an orbital mixer at $120 \mathrm{rpm}$ for 20 
min. Subsequently, 10-fold dilutions were prepared to quantify the different microbial groups. The LAB were enumerated using MRS agar (Difco) containing 0.1\% cysteine-HCl (Merck, Dasmstadt, Germany) and 0.4\% cycloheximide (0.4\%; Sigma) after anaerobic incubation (AnaeroGen; Oxoid). The plates were incubated at $30^{\circ} \mathrm{C}$ for $48 \mathrm{~h}$. Yeast and filamentous fungi were enumerated on dichloran rose bengal chloramphenicol medium (Difco) after incubating the plates at $28^{\circ} \mathrm{C}$ for $72 \mathrm{~h}$. For all of the microorganisms, only plates containing between 30 and 300 cfu were enumerated.

Assessment of Aerobic Stability of Silages. After $61 \mathrm{~d}$ of ensiling, the mini-silos were opened and triplicate samples of approximately $3 \mathrm{~kg}$ were removed from each mini-silo and placed in 5-kg plastic buckets to assess their aerobic stability. A thermometer was inserted into the silage mass to a depth of $10 \mathrm{~cm}$ for 7 $\mathrm{d}$. The containers were kept in a room with a controlled temperature of $26^{\circ} \mathrm{C}\left( \pm 1.5^{\circ} \mathrm{C}\right)$. The silage temperature was recorded every $8 \mathrm{~h}$. The room temperature was measured using a thermometer located close to the buckets. The aerobic stability was defined as the number of hours that the silage remained stable before increasing more than $2^{\circ} \mathrm{C}$ above the room temperature (O'Kiely, 1993).

\section{Statistical Analysis}

The metabolite production data were evaluated by PCA using XL Stat software (version 7.5; Universidade Federal de Lavras, Lavras, Brazil). The experiment evaluating anaerobic fermentation was conducted in a completely randomized design with 15 treatments and 3 replicates. Statistical analysis was performed using SisVar software (version 4.5; SisVar, Lavras, Brazil). The means were compared by the Scott-Knott test.

\section{RESULTS}

\section{Experiment 1: Isolation and Characterization of LAB from Sugar Cane Silage}

The size of the LAB population ranged from 4.8 to $8.7 \log \mathrm{cfu} / \mathrm{g}$ of sugar cane silage after $0,2,15$, and 60 $\mathrm{d}$ of ensiling (Table 1). The number of different colony morphotypes found at each time of opening ranged from 4 to 8 . All 81 of the obtained isolates were classified as rod-shaped, gram-positive bacteria that were catalase-, oxidase-, and motility-negative. Based on the identification keys proposed by Hammes and Hertel (2003), the isolates were identified as belonging to the Lactobacillus genus and were classified as homofermentative or heterofermentative (Table 2).

Preselection of Bacterial Strains Based on Metabolite Production in Sugar Cane Broth. Of
Table 1. Experiment 1: $\mathrm{pH}$ values, population of lactic acid bacteria (LAB), number of morphotypes, and number of bacterial isolates from sugar cane silages at different fermentation times

\begin{tabular}{lcccc}
\hline $\begin{array}{l}\text { Time of } \\
\text { fermentation } \\
\text { (d) }\end{array}$ & $\mathrm{pH}$ & $\begin{array}{c}\text { LAB count } \\
\text { (log cfu/g of silage) }\end{array}$ & $\begin{array}{c}\text { No. of } \\
\text { morphotypes }\end{array}$ & $\begin{array}{c}\text { No. of } \\
\text { isolates }\end{array}$ \\
\hline 0 & 5.1 & 4.8 & 8 & 16 \\
2 & 3.8 & 6.0 & 4 & 20 \\
15 & 3.5 & 7.2 & 5 & 16 \\
60 & 3.5 & 8.7 & 7 & 29 \\
\hline
\end{tabular}

the 81 LAB isolates, 24 did not grow in sugar cane broth and thus were not assessed in the subsequent tests for metabolite production (data not shown). The concentrations of metabolites produced by the $57 \mathrm{LAB}$ strains in sugar cane broth were highly variable (Table 2 ). The concentrations of lactic, acetic, and propionic acids, ethanol, and 1,2-propanediol ranged from 0.88 to $8.5,0.89$ to $6.12,0$ to $0.46,0$ to 0.05 , and 0 to $0.07 \mathrm{~g} / \mathrm{L}$, respectively.

The data from Table 2 were subject to PCA to obtain a better view of the relationship between microbial metabolites and the LAB strains used for the sugar cane ensiling. Principal component analysis uses a mathematical procedure that transforms a set of possibly correlated response variables into a new set of noncorrelated variables called principal components (PC). Thus, PCA can be used to reduce the number of original variables to a smaller number, or PC, by keeping only the largest or most significant PC (Brereton, 2000). The PCA (Figure 1) showed that it was possible to correlate the strains with their produced metabolites, grouping them according to the concentrations obtained for the analyzed metabolites. The strains that were correlated with propionic acid were also correlated with ethanol, whereas those that were characterized by lactic acid production also produced 1,2-propanediol. Some isolates did not correlate effectively with any of the desired metabolites in the silage and were not used in subsequent steps of strain selection.

Based on previously described results, some strains that produced high amounts of each of the metabolites of interest (acetic, lactic, and propionic acids) were chosen, and a new experiment was conducted with these strains in experimental silos to assess the silage characteristics. Five strains that produced the highest acetic acid concentrations (UFLA SIL17, UFLA SIL24, UFLA SIL25, UFLA SIL27, and UFLA SIL35), 4 strains that produced the highest amounts of lactic acid (UFLA SIL19, UFLA SIL32, UFLA SIL33, and UFLA SIL34), and 5 strains that produced the highest amounts of propionic acid (UFLA SIL41, UFLA SIL42, UFLA SIL46, UFLA SIL51, and UFLA SIL52) were chosen for experimental silos (Figure 1). 
ÁVILA ET AL.

Table 2. Contents (g/L) of lactic, acetic, and propionic acids, ethanol, and 1,2-propanediol by strains of lactic acid bacteria (LAB) in sugar cane broth

\begin{tabular}{|c|c|c|c|c|c|c|}
\hline LAB strain & $\operatorname{Gas}^{1}$ & Lactic acid & Acetic acid & Propionic acid & Ethanol & 1,2-Propanediol \\
\hline UFLA SIL1 & - & 1.84 & 3.28 & $\mathrm{ND}^{2}$ & 0.02 & ND \\
\hline UFLA SIL2 & - & 2.04 & 3.09 & ND & 0.02 & ND \\
\hline UFLA SIL3 & - & 2.03 & 2.58 & 0.13 & 0.02 & ND \\
\hline UFLA SIL4 & - & 2.02 & 3.13 & 0.12 & ND & ND \\
\hline UFLA SIL5 & - & 2.09 & 3.14 & 0.12 & 0.02 & ND \\
\hline UFLA SIL6 & - & 2.08 & 2.67 & ND & 0.02 & ND \\
\hline UFLA SIL7 & - & 4.43 & 1.44 & 0.13 & 0.02 & ND \\
\hline UFLA SIL8 & - & 1.43 & 2.49 & 0.12 & 0.02 & ND \\
\hline UFLA SIL9 & - & 1.65 & 2.98 & 0.15 & ND & ND \\
\hline UFLA SIL10 & - & 1.83 & 2.26 & 0.13 & ND & ND \\
\hline UFLA SIL11 & - & 1.25 & 2.64 & 0.12 & 0.02 & ND \\
\hline UFLA SIL12 & - & 0.88 & 2.22 & 0.10 & 0.02 & ND \\
\hline UFLA SIL14 & - & 7.11 & 2.49 & 0.13 & 0.02 & 0.06 \\
\hline UFLA SIL15 & - & 6.26 & 2.11 & 0.14 & 0.02 & 0.06 \\
\hline UFLA SIL16 & - & 1.15 & 2.76 & 0.14 & 0.03 & 0.07 \\
\hline UFLA SIL17 $^{3}$ & + & 4.50 & 6.12 & 0.07 & 0.02 & ND \\
\hline UFLA SIL18 & + & 7.48 & 2.55 & 0.10 & 0.02 & 0.06 \\
\hline UFLA SIL $19^{4}$ & + & 8.11 & 2.46 & 0.08 & 0.03 & 0.06 \\
\hline UFLA SIL20 & + & 7.45 & 1.90 & ND & 0.02 & ND \\
\hline UFLA SIL21 & + & 7.38 & 2.31 & 0.17 & 0.02 & 0.05 \\
\hline UFLA SIL22 & + & 7.49 & 1.72 & 0.10 & 0.02 & ND \\
\hline UFLA SIL23 & + & 7.39 & 2.31 & 0.07 & 0.02 & 0.05 \\
\hline UFLA SIL $24^{3}$ & + & 1.93 & 4.16 & 0.12 & 0.03 & ND \\
\hline UFLA SIL $25^{3}$ & + & 1.95 & 4.14 & 0.12 & 0.03 & ND \\
\hline UFLA SIL26 & - & 2.05 & 4.18 & 0.12 & 0.03 & ND \\
\hline UFLA SIL $27^{3}$ & + & 2.01 & 4.21 & 0.12 & 0.03 & ND \\
\hline UFLA SIL28 & - & 1.83 & 3.71 & 0.11 & 0.03 & ND \\
\hline UFLA SIL29 & - & 2.19 & 3.76 & 0.10 & 0.03 & ND \\
\hline UFLA SIL30 & - & 8.01 & 2.75 & 0.04 & 0.02 & 0.06 \\
\hline UFLA SIL31 & - & 7.50 & 2.70 & ND & 0.02 & 0.05 \\
\hline UFLA SIL $32^{4}$ & + & 7.67 & 2.52 & 0.06 & 0.02 & 0.06 \\
\hline UFLA SIL $33^{4}$ & + & 7.56 & 2.29 & 0.04 & 0.02 & 0.06 \\
\hline UFLA SIL $34^{4}$ & + & 8.50 & 2.28 & 0.08 & 0.02 & 0.06 \\
\hline UFLA SIL $35^{3}$ & + & 3.56 & 3.96 & 0.05 & 0.02 & 0.06 \\
\hline UFLA SIL36 & - & 1.59 & 3.39 & 0.11 & 0.03 & 0.00 \\
\hline UFLA SIL37 & + & 5.72 & 2.60 & 0.18 & 0.02 & 0.07 \\
\hline UFLA SIL38 & - & 1.81 & 3.65 & 0.12 & 0.03 & 0.06 \\
\hline UFLA SIL39 & + & 6.94 & 2.42 & 0.08 & 0.02 & 0.06 \\
\hline UFLA SIL40 & + & 7.13 & 0.89 & 0.17 & 0.02 & 0.06 \\
\hline UFLA SIL $41^{5}$ & + & 6.82 & 1.90 & 0.21 & 0.02 & 0.07 \\
\hline UFLA SIL $42^{5}$ & + & 3.01 & 2.76 & 0.22 & 0.02 & 0.07 \\
\hline UFLA SIL43 & + & 3.98 & 2.41 & 0.22 & 0.02 & 0.06 \\
\hline UFLA SIL44 & + & 7.61 & 1.90 & 0.08 & 0.02 & 0.06 \\
\hline UFLA SIL45 & + & 7.40 & 1.76 & 0.11 & 0.02 & 0.06 \\
\hline UFLA SIL $46^{5}$ & + & 3.60 & 2.46 & 0.22 & 0.02 & 0.07 \\
\hline UFLA SIL47 & + & 4.26 & 2.28 & 0.17 & 0.02 & 0.06 \\
\hline UFLA SIL48 & + & 3.48 & 3.33 & 0.12 & 0.02 & 0.06 \\
\hline UFLA SIL49 & + & 4.38 & 2.83 & 0.14 & 0.02 & 0.06 \\
\hline UFLA SIL50 & - & 1.51 & 3.03 & 0.13 & 0.03 & 0.06 \\
\hline UFLA SIL51 $1^{5}$ & + & 3.16 & 3.60 & 0.23 & 0.03 & ND \\
\hline UFLA SIL5 $2^{5}$ & + & 3.37 & 3.79 & 0.46 & 0.05 & ND \\
\hline UFLA SIL53 & - & 3.57 & 3.52 & 0.20 & 0.05 & ND \\
\hline UFLA SIL54 & - & 5.89 & 2.64 & ND & 0.02 & ND \\
\hline UFLA SIL55 & - & 4.35 & 3.60 & 0.12 & 0.03 & 0.05 \\
\hline UFLA SIL56 & - & 1.96 & 3.12 & 0.11 & 0.03 & ND \\
\hline UFLA SIL57 & - & 6.21 & 1.79 & 0.15 & 0.02 & ND \\
\hline UFLA SIL58 & - & 7.07 & 1.83 & 0.21 & 0.02 & ND \\
\hline
\end{tabular}

${ }^{1}$ Heterofermentative strains producing gas from either glucose or gluconate producers. Isolates from time 0 of fermentation: UFLA SIL1 to UFLA SIL16; isolates from $2 \mathrm{~d}$ of fermentation time: UFLA SIL17 to UFLA SIL36; isolates from $15 \mathrm{~d}$ of fermentation: UFLA SIL37 to UFLA SIL50; isolates from $60 \mathrm{~d}$ of fermentation: UFLA SIL51 to UFLA SIL57.

${ }^{2}$ Not detected.

${ }^{3}$ Best acetic acid-producing strains.

${ }^{4}$ Best lactic acid-producing strains.

${ }^{5}$ Best propionic acid-producing strains. 


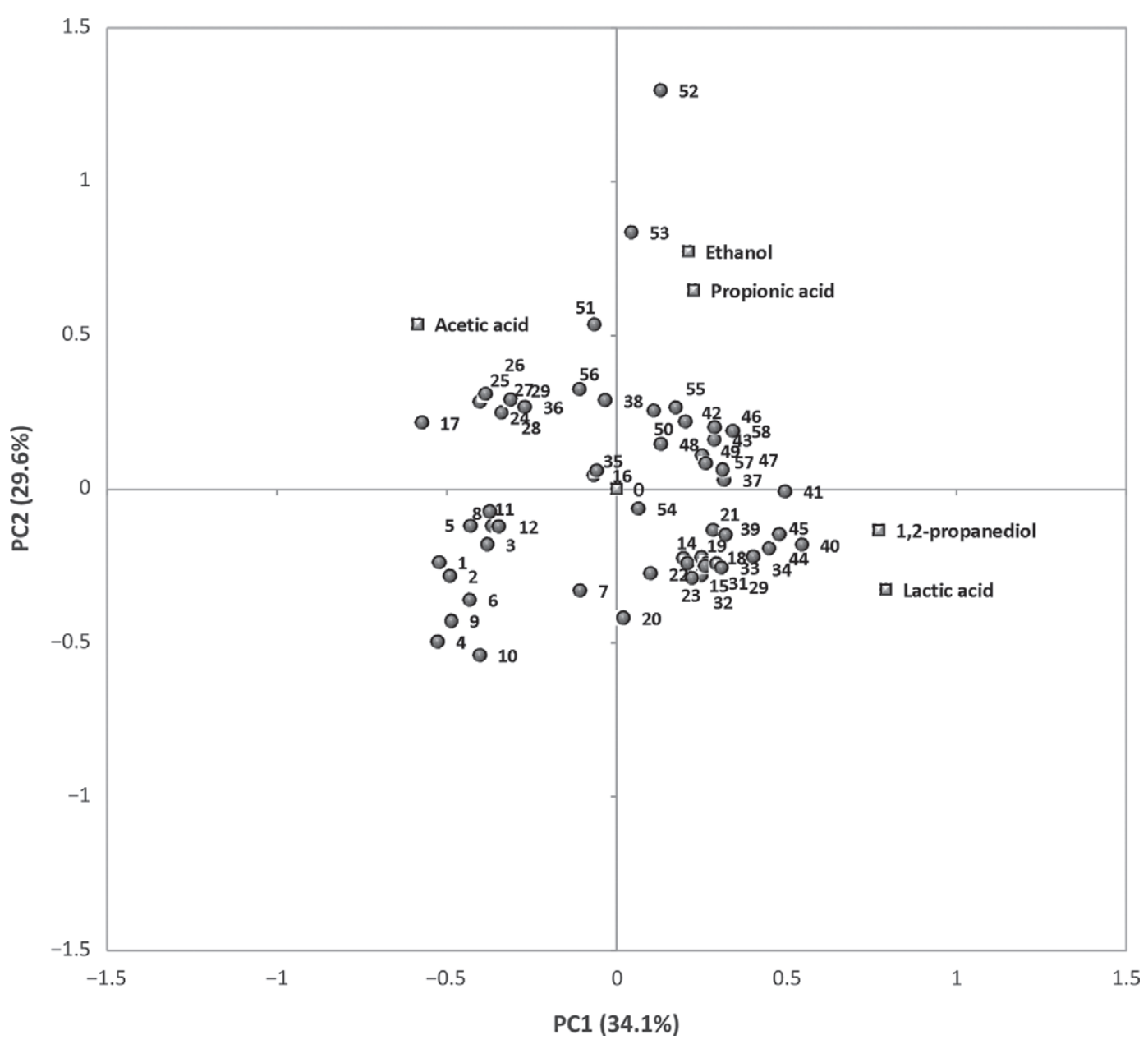

Figure 1. Principal component (PC) analysis of metabolites produced during fermentation of sugar cane broth by lactic acid bacteria. The numbers represent the strains defined in Table 2.

Molecular Identification of Selected Strains. The strains that were selected based on their production of acetic, lactic, and propionic acids were identified as belonging to 3 different species: $L b$. plantarum, $L b$. brevis, and $L b$. hilgardii, with sequence identity $>97 \%$ (Table 3).

\section{Experiment 2: Evaluation of Strains in Experimental Silos}

Chemical and Microbiological Characteristics of Silage. The use of inoculated strains affected $(P<$ 0.001) DM losses and NDF content in the sugar cane silage (Table 4). In the silages inoculated with strains UFLA SIL17, UFLA SIL24, UFLA SIL25, UFLA SIL27, UFLA SIL33, UFLA SIL51, and UFLA SIL52, lower DM losses were found compared with the control. Inoculation with these strains also resulted in silage with a higher DM content and lower NDF. The inoculants did not influence $(P=0.91) \mathrm{pH}$ or water-soluble carbohydrates content of the silage, whose mean values were of 3.61 and $25.9 \mathrm{~g} / \mathrm{kg}$ of DM, respectively.

The populations of LAB $(P<0.001)$ and yeast $(P=$ 0.02 ) differed among the silages (Table 4 ). All silages inoculated with LAB strains showed a reduction in LAB population compared with the control, except for those inoculated with UFLA SIL51 and UFLA SIL52 strains. The yeast population was larger in the silage inoculated with UFLA SIL19, UFLA SIL32, UFLA SIL42, and UFLA SIL46 strains. Among the remaining silage samples, the yeast population was smaller than those previously reported.

The production of metabolites after $60 \mathrm{~d}$ of fermentation was influenced $(P<0.01)$ by the addition of inoculants (Table 5). The silage inoculated with the UFLA SIL19, UFLA SIL32, UFLA SIL34, UFLA SIL35, UFLA SIL41, UFLA SIL42, and UFLA SIL46 strains showed high levels of lactic acid and ethanol, similar to the control silage. The use of UFLA SIL51 and UFLA SIL52 strains resulted in silage with similar levels of 
Table 3. Experiment 1: Isolates, bacterial species, and percentage similarity of bacteria isolated from sugar cane silages

\begin{tabular}{|c|c|c|c|}
\hline Isolate & Species & $\begin{array}{c}\text { Similarity } \\
(\%)\end{array}$ & $\begin{array}{l}\mathrm{NCBI}^{1} \\
\text { accession no. }\end{array}$ \\
\hline UFLA SIL17 $7^{2}$ & Lactobacillus brevis & 97 & FJ532364.1 \\
\hline UFLA SIL $19^{3}$ & Lactobacillus plantarum & 98 & FJ669130.1 \\
\hline UFLA SIL $24^{2}$ & $L b$. brevis & 99 & FJ227316.1 \\
\hline UFLA SIL $25^{2}$ & Lb. brevis & 98 & FJ227316.1 \\
\hline UFLA SIL $27^{2}$ & Lb. brevis & 98 & FJ227316.1 \\
\hline UFLA SIL $32^{3}$ & Lb. plantarum & 99 & HM218291.1 \\
\hline UFLA SIL $33^{3}$ & Lb. brevis & 98 & FJ227316.1 \\
\hline UFLA SIL $34^{3}$ & Lb. plantarum & 98 & HM218291.1 \\
\hline UFLA SIL $35^{2}$ & Lb. plantarum & 98 & HM218291.1 \\
\hline UFLA SIL $41^{4}$ & Lb. plantarum & 99 & HM218291.1 \\
\hline UFLA SIL $42^{4}$ & Lb. plantarum & 99 & HM218291.1 \\
\hline UFLA SIL $46^{4}$ & Lb. plantarum & 99 & HM218291.1 \\
\hline UFLA SIL51 ${ }^{4}$ & Lactobacillus hilgardii & 98 & HM217951.1 \\
\hline UFLA SIL5 $2^{4}$ & Lb. hilgardii & 98 & HM218291.1 \\
\hline
\end{tabular}

${ }^{1}$ National Center for Biotechnology Information (http://www.ncbi.nlm.nih.gov/).

${ }^{2}$ Best acetic acid-producing strains.

${ }^{3}$ Best lactic acid-producing strains.

${ }^{4}$ Best propionic acid-producing strains.

acetic acid and 1,2-propanediol, which were higher than in the other silages. The acetic acid levels in the silage inoculated with UFLA SIL17, UFLA SIL24, UFLA SIL25, UFLA SIL27, UFLA SIL33, and UFLA SIL42 strains were similar and showed no difference from the control silage. However, these acetic acid levels were higher than those found for the silage inoculated with the UFLA SIL19, UFLA SIL32, UFLA SIL34, UFLA
SIL35, UFLA SIL41, and UFLA SIL46 strains, which showed the lowest acetic acid levels. The propionic acid levels were higher in the silage inoculated with the UFLA SIL17, UFLA SIL25, UFLA SIL27, UFLA SIL32, UFLA SIL33, UFLA SIL34, UFLA SIL35, and UFLA SIL41 strains than the other silages. For the other silages, the propionic acid levels were low and similar, consistent with the control silage. The concentrations

Table 4. Experiment 2: Chemical composition ${ }^{1}$ of fresh sugar cane and sugar cane silages at $61 \mathrm{~d}$ of ensilage without inoculants and inoculated with different lactic acid bacteria strains

\begin{tabular}{|c|c|c|c|c|c|c|c|}
\hline Silage treatment & $\begin{array}{c}\text { DM } \\
(\mathrm{g} / \mathrm{kg} \text { of } \mathrm{FM})\end{array}$ & $\begin{array}{l}\text { DM loss } \\
(\%)\end{array}$ & $\begin{array}{c}\mathrm{NDF} \\
(\mathrm{g} / \mathrm{kg} \text { of } \mathrm{DM})\end{array}$ & $\begin{array}{c}\text { WSC } \\
(\mathrm{g} / \mathrm{kg} \text { of } \mathrm{DM})\end{array}$ & $\mathrm{pH}$ & $\begin{array}{c}\text { LAB } \\
(\log \mathrm{cfu} / \mathrm{g})\end{array}$ & $\begin{array}{c}\text { Yeasts } \\
(\mathrm{g} / \mathrm{kg} \text { of } \mathrm{DM})\end{array}$ \\
\hline Fresh sugar cane & 282 & - & 480 & 247 & 5.75 & 7.51 & 5.72 \\
\hline Control & $246.2^{\mathrm{b}}$ & $22.61^{\mathrm{a}}$ & $617.9^{\mathrm{b}}$ & 25.3 & 3.60 & $8.16^{\mathrm{a}}$ & $5.38^{\mathrm{b}}$ \\
\hline UFLA SIL $17^{2}$ & $264.1^{\mathrm{a}}$ & $15.87^{\mathrm{b}}$ & $568.7^{\mathrm{b}}$ & 25.5 & 3.61 & $6.48^{\mathrm{b}}$ & $4.57^{\mathrm{b}}$ \\
\hline UFLA SIL $19^{3}$ & $235.6^{\mathrm{b}}$ & $28.19^{\mathrm{a}}$ & $678.8^{\mathrm{a}}$ & 33.4 & 3.6 & $5.98^{\mathrm{b}}$ & $6.48^{\mathrm{a}}$ \\
\hline UFLA SIL $24^{2}$ & $263.1^{\mathrm{a}}$ & $18.10^{\mathrm{b}}$ & $590.8^{\mathrm{b}}$ & 24.3 & 3.62 & $5.55^{\mathrm{b}}$ & $5.35^{\mathrm{b}}$ \\
\hline UFLA SIL $25^{2}$ & $258.9^{\mathrm{a}}$ & $17.13^{\mathrm{b}}$ & $578.6^{\mathrm{b}}$ & 30.8 & 3.61 & $7.37^{\mathrm{b}}$ & $5.12^{\mathrm{b}}$ \\
\hline UFLA SIL $27^{2}$ & $261.7^{\mathrm{a}}$ & $19.32^{\mathrm{b}}$ & $609.2^{\mathrm{b}}$ & 24.0 & 3.63 & $7.02^{\mathrm{b}}$ & $4.58^{\mathrm{b}}$ \\
\hline UFLA SIL $32^{3}$ & $239.4^{\mathrm{b}}$ & $25.50^{\mathrm{a}}$ & $648.5^{\mathrm{a}}$ & 32.3 & 3.61 & $6.44^{\mathrm{b}}$ & $6.17^{\mathrm{a}}$ \\
\hline UFLA SIL $33^{3}$ & $260.7^{\mathrm{a}}$ & $18.86^{\mathrm{b}}$ & $600.5^{\mathrm{b}}$ & 23.2 & 3.62 & $6.76^{\mathrm{b}}$ & $4.81^{\mathrm{b}}$ \\
\hline UFLA SIL34 ${ }^{3}$ & $241.5^{\mathrm{b}}$ & $26.49^{\mathrm{a}}$ & $682.3^{\mathrm{a}}$ & 21.6 & 3.64 & $7.09^{\mathrm{b}}$ & $4.98^{\mathrm{b}}$ \\
\hline UFLA SIL $35^{2}$ & $241.3^{\mathrm{b}}$ & $26.49^{\mathrm{a}}$ & $676.9^{\mathrm{a}}$ & 24.6 & 3.64 & $6.93^{\mathrm{b}}$ & $5.08^{\mathrm{b}}$ \\
\hline UFLA SIL41 ${ }^{4}$ & $238.5^{\mathrm{b}}$ & $26.83^{\mathrm{a}}$ & $672.2^{\mathrm{a}}$ & 31.6 & 3.58 & $6.82^{\mathrm{b}}$ & $5.20^{\mathrm{b}}$ \\
\hline UFLA SIL $42^{4}$ & $241.4^{\mathrm{b}}$ & $24.22^{\mathrm{a}}$ & $670.4^{\mathrm{a}}$ & 25.4 & 3.61 & $7.28^{\mathrm{b}}$ & $5.88^{\mathrm{a}}$ \\
\hline UFLA SIL $46^{4}$ & $239.2^{\mathrm{b}}$ & $24.91^{\mathrm{a}}$ & $680.4^{\mathrm{a}}$ & 21.2 & 3.62 & $6.43^{\mathrm{b}}$ & $6.22^{\mathrm{a}}$ \\
\hline UFLA SIL51 ${ }^{4}$ & $264.8^{\mathrm{a}}$ & $14.90^{\mathrm{b}}$ & $598.0^{\mathrm{b}}$ & 23.4 & 3.61 & $8.36^{\mathrm{a}}$ & $4.61^{\mathrm{b}}$ \\
\hline UFLA SIL $52^{4}$ & $259.6^{\mathrm{a}}$ & $15.39^{\mathrm{b}}$ & $616.7^{\mathrm{b}}$ & 21.1 & 3.66 & $8.40^{\mathrm{a}}$ & $4.83^{\mathrm{b}}$ \\
\hline Average & 250.4 & 21.65 & 632.6 & 25.9 & 3.61 & 7.0 & 5.28 \\
\hline$P$-value & $<0.001$ & $<0.001$ & $<0.001$ & 0.59 & 0.91 & $<0.001$ & 0.018 \\
\hline SEM & 4.4 & 17.5 & 16.2 & 4.4 & 0.3 & 3.7 & 3.9 \\
\hline
\end{tabular}

${ }^{\mathrm{a}, \mathrm{b}}$ Means within columns with different superscripts differ $(P<0.05)$ by the Scott-Knott test.

${ }^{1} \mathrm{FM}=$ fresh matter; WSC $=$ water-soluble carbohydrates; LAB = lactic acid bacteria.

${ }^{2}$ Best acetic acid-producing strains.

${ }^{3}$ Best lactic acid-producing strains.

${ }^{4}$ Best propionic acid-producing strains. 
Table 5. Experiment 2: Concentrations ( $\mathrm{g} / \mathrm{kg}$ of DM) of lactic, acetic, propionic, and butyric acids, ethanol, and 1,2-propanediol of sugar cane silages at $61 \mathrm{~d}$ of ensilage without inoculants and inoculated with different lactic acid bacteria strain

\begin{tabular}{lcccccc}
\hline Silage treatment & $\begin{array}{c}\text { Lactic } \\
\text { acid }\end{array}$ & $\begin{array}{c}\text { Acetic } \\
\text { acid }\end{array}$ & $\begin{array}{c}\text { Propionic } \\
\text { acid }\end{array}$ & $\begin{array}{c}\text { Butyric } \\
\text { acid }\end{array}$ & Ethanol & 1,2 -Propanediol \\
\hline Control & $46.6^{\mathrm{a}}$ & $9.7^{\mathrm{b}}$ & $3.1^{\mathrm{b}}$ & $0.0^{\mathrm{b}}$ & $137.0^{\mathrm{a}}$ & $1.7^{\mathrm{b}}$ \\
UFLA SIL17 $^{1}$ & $35.5^{\mathrm{b}}$ & $10.5^{\mathrm{b}}$ & $6.5^{\mathrm{a}}$ & $2.3^{\mathrm{a}}$ & $76.2^{\mathrm{b}}$ & $0.7^{\mathrm{c}}$ \\
UFLA SIL19 $^{\mathrm{b}}$ & $55.3^{\mathrm{a}}$ & $5.9^{\mathrm{c}}$ & $3.4^{\mathrm{b}}$ & $0.0^{\mathrm{b}}$ & $189.3^{\mathrm{a}}$ & $0.5^{\mathrm{c}}$ \\
UFLA SIL 24 $^{1}$ & $36.4^{\mathrm{b}}$ & $10.4^{\mathrm{b}}$ & $3.4^{\mathrm{b}}$ & $2.6^{\mathrm{a}}$ & $94.4^{\mathrm{b}}$ & $0.5^{\mathrm{c}}$ \\
UFLA SIL25 $^{1}$ & $36.8^{\mathrm{b}}$ & $10.5^{\mathrm{b}}$ & $5.2^{\mathrm{a}}$ & $3.6^{\mathrm{a}}$ & $88.9^{\mathrm{b}}$ & $0.6^{\mathrm{c}}$ \\
UFLA SIL27 $^{1}$ & $35.7^{\mathrm{b}}$ & $9.9^{\mathrm{b}}$ & $5.1^{\mathrm{a}}$ & $3.6^{\mathrm{a}}$ & $102.7^{\mathrm{b}}$ & $0.6^{\mathrm{c}}$ \\
UFLA SIL32 $^{\mathrm{a}}$ & $51.8^{\mathrm{a}}$ & $39^{\mathrm{c}}$ & $7.6^{\mathrm{a}}$ & $3.3^{\mathrm{a}}$ & $210.1^{\mathrm{a}}$ & $0.6^{\mathrm{c}}$ \\
UFLA SIL33 $^{2}$ & $34.5^{\mathrm{b}}$ & $9.8^{\mathrm{b}}$ & $7.4^{\mathrm{a}}$ & $2.5^{\mathrm{a}}$ & $87.2^{\mathrm{b}}$ & $0.6^{\mathrm{c}}$ \\
UFLA SIL34 $^{2}$ & $48.5^{\mathrm{a}}$ & $4.1^{\mathrm{c}}$ & $5.4^{\mathrm{a}}$ & $4.9^{\mathrm{a}}$ & $217.8^{\mathrm{a}}$ & $0.6^{\mathrm{c}}$ \\
UFLA SIL35 $^{1}$ & $43.7^{\mathrm{a}}$ & $3.3^{\mathrm{c}}$ & $6.4^{\mathrm{a}}$ & $3.5^{\mathrm{a}}$ & $185.8^{\mathrm{a}}$ & $0.6^{\mathrm{c}}$ \\
UFLA SIL41 $^{3}$ & $47.9^{\mathrm{a}}$ & $3.6^{\mathrm{c}}$ & $6.6^{\mathrm{a}}$ & $3.2^{\mathrm{a}}$ & $208.3^{\mathrm{a}}$ & $0.7^{\mathrm{c}}$ \\
UFLA SIL42 $^{3}$ & $48.0^{\mathrm{a}}$ & $8.9^{\mathrm{b}}$ & $3.3^{\mathrm{b}}$ & $0.4^{\mathrm{b}}$ & $187.4^{\mathrm{a}}$ & $0.6^{\mathrm{c}}$ \\
UFLA SIL46 $^{3}$ & $43.7^{\mathrm{a}}$ & $3.2^{\mathrm{c}}$ & $3.5^{\mathrm{b}}$ & $1.9^{\mathrm{b}}$ & $180.4^{\mathrm{a}}$ & $0.6^{\mathrm{c}}$ \\
UFLA SIL51 $^{3}$ & $34.6^{\mathrm{b}}$ & $19.7^{\mathrm{a}}$ & $4.0^{\mathrm{b}}$ & $1.2^{\mathrm{b}}$ & $39.9^{\mathrm{c}}$ & $3.27^{\mathrm{a}}$ \\
UFLA SIL52 $^{3}$ & $31.4^{\mathrm{b}}$ & $22.5^{\mathrm{a}}$ & $4.1^{\mathrm{b}}$ & $1.3^{\mathrm{b}}$ & $44.4^{\mathrm{c}}$ & $3.98^{\mathrm{a}}$ \\
Average $_{\text {P-value }}$ & 42.0 & 9.1 & 5.0 & 2.2 & 136.7 & 0.54 \\
SEM & $<0.001$ & $<0.001$ & 0.01 & 0.001 & $<0.001$ & $<0.001$ \\
\hline
\end{tabular}

${ }^{\mathrm{a}-\mathrm{c}}$ Means within columns with different superscripts differ $(P<0.05)$ by Scott-Knott test.

${ }^{1}$ Best acetic acid-producing strains.

${ }^{2}$ Best lactic acid-producing strains.

${ }^{3}$ Best propionic acid-producing strains.

of butyric acid were lower in the silage inoculated with the UFLA SIL19, UFLA SIL42, UFLA SIL46, UFLA SIL51, and UFLA SIL52 strains, similar to the control $(P>0.05)$. The other silage showed similar levels of butyric acid.

Temperature of Silage After Opening the Silos. We observed no differences $(P>0.05)$ among silages in aerobic stability, maximum temperature reached by the silage, or time to reach this maximum temperature (Table 6). The average of the maximum temperature reached by the silage ranged from $41.8^{\circ} \mathrm{C}$ (UFLA SIL19) to $45.7^{\circ} \mathrm{C}$ (UFLA SIL17), and the time to reach this maximum temperature varied from $29.3 \mathrm{~h}$ (UFLA SIL24) to $53.3 \mathrm{~h}$ (UFLA SIL19, UFLA SIL42, and UFLA SIL46). The temperature of the control silage was stable for approximately $21.3 \mathrm{~h}$, whereas that of the silage produced with the inoculants was stable for periods ranging from 18.7 to $29.3 \mathrm{~h}$ (Table 6).

\section{DISCUSSION}

The isolation of bacteria using MRS medium allowed identification of different morphotypes each time the silos were opened, and all of the isolates were classified as Lactobacillus genus, as reported by Ávila et al. (2009). De Man, Rogosa, and Sharpe medium enables the growth of other LAB genera (Hammes and Hertel, 2003), although at none of the silo opening times in the current study did we detect growth of LAB from other genera. Bacteria belonging to the genus Lactobacillus are among those most commonly used as silage inoculants, because of the high tolerance of these microorganisms to acidic environments, such as sugar cane silage, whose $\mathrm{pH}$ value is approximately 3.5 at the final fermentation steps of silage (Ávila et al., 2009). Bacteria of the Lactobacillus genus are usually responsible for the final fermentation steps of ensilage and other plants (Daeschel et al., 1987; McDonald et al., 1991).

Despite the low diversity of LAB found in silages here, great diversity in their metabolism was observed (Table 2). According to Axelsson (2004), the Lactobacillus genus is the most heterogeneous within the LAB group, with species exhibiting widely variable phenotypic, physiological, and biochemical characteristics.

The major metabolic variations of these bacteria were found in their production of lactic and acetic acids. In general, LAB produce lactic acid as the main product of carbohydrate fermentation, but some of the isolated strains produced more acetic acid than lactic acid (Table 2). This occurred because LAB can adapt to diverse conditions by altering their metabolism. To utilize hexoses, LAB primarily use 2 main pathways, the first of which is glycolysis, which is characterized by the formation of fructose-1,6-diphosphate. Under normal conditions of high sugar content and limited access to oxygen, pyruvate is reduced to lactic acid, a metabolic pathway known as homolactic fermentation. The other main fermentation pathway is the pentose 
ÁVILA ET AL.

Table 6. Aerobic stability of sugar cane silages with inoculants

\begin{tabular}{lccc}
\hline Silage treatment & $\begin{array}{c}\text { Aerobic } \\
\text { stability }(\mathrm{h})\end{array}$ & $\begin{array}{c}\text { Maximum } \\
\text { temperature }\left({ }^{\circ} \mathrm{C}\right)\end{array}$ & $\begin{array}{c}\text { Time to reach } \\
\text { maximum temperature }(\mathrm{h})\end{array}$ \\
\hline Control & 21.36 & 43.7 & 45.3 \\
UFLA SIL 17 $^{1}$ & 18.7 & 45.7 & 37.3 \\
UFLA SIL19 $^{2}$ & 21.36 & 41.8 & 53.3 \\
UFLA SIL24 $^{1}$ & 24.0 & 43.5 & 48.0 \\
UFLA SIL25 $^{1}$ & 21.3 & 45.3 & 40.0 \\
UFLA SIL27 $^{1}$ & 24.0 & 45.0 & 48.0 \\
UFLA SIL32 $^{2}$ & 18.7 & 43.3 & 37.3 \\
UFLA SIL33 $^{2}$ & 21.3 & 45.3 & 37.3 \\
UFLA SIL34 $^{2}$ & 21.3 & 43.0 & 29.3 \\
UFLA SIL35 $^{1}$ & 24.0 & 43.7 & 47.3 \\
UFLA SIL41 $^{3}$ & 24.0 & 44.2 & 53.3 \\
UFLA SIL42 $^{3}$ & 21.3 & 42.3 & 53.3 \\
UFLA SIL46 $^{3}$ & 29.3 & 43.0 & 50.7 \\
UFLA SIL51 $^{3}$ & 26.7 & 44.0 & 48.0 \\
UFLA SIL52 $^{3}$ & 21.3 & 44.3 & 0.48 \\
P-value & 0.42 & 0.07 & 7.38 \\
SEM (\%) & 2.73 & 0.81 & \\
\hline
\end{tabular}

${ }^{1}$ Best acetic acid-producing strains.

${ }^{2}$ Best lactic acid-producing strains.

${ }^{3}$ Best propionic acid-producing strains.

phosphate pathway, which is characterized by initial dehydrogenation, followed by decarboxylation leading to significant amounts of other end products, including $\mathrm{CO}_{2}$, ethanol, or acetic acid; this metabolism is referred to as heterolactic fermentation (Axelsson, 2004). The classification of LAB as homo- or heterofermentative is based on the presence or absence of key enzymes used in each pathway, including fructose-1,6-diphosphate aldolase and phosphoketolase (Kandler, 1983; Kandler and Weiss, 1986). Therefore, lactic and acetic acids are the major products of LAB metabolism, which can vary as a result of the ability of bacteria to use a given metabolic pathway for a particular type of substrate (Axelsson, 2004).

The PCA (Figure 1) showed no correlation between the best producers of lactic acid and the best producers of acetic acid or ethanol and propionic acid. Therefore, in a selection process, it is unlikely that a strain selected as the best producer of lactic acid will also be the best producer of acetic acid.

We found no studies in the literature that describe the production of propionic acid by a single strain of Lactobacillus in a simple culture. However, Oude Elferink et al. (2001) showed that strains of Lb. buchneri and $L b$. parabuchneri in a simple culture were able to degrade lactic acid under anoxic conditions without an external electron acceptor such as 1,2-propanediol. Krooneman et al. (2002) showed that a new species named Lactobacillus diolivorans was able to degrade the 1,2-propanediol present in the medium into 1-propanol and propionic acid. The strains used in our study were isolated from silage and have not yet been studied in detail and their metabolism may not be fully understood.

Molecular identification showed that of the 4 strains chosen for their high production of lactic acid, 3 were Lb. plantarum (UFLA SIL19, UFLA SIL32, and UFLA SIL34) and 1 was $L b$. brevis (UFLA SIL33). Of the 5 strains chosen for their high production of acetic acid, 4 were identified as $L b$. brevis (UFLA SIL17, UFLA SIL24, UFLA SIL25, and UFLA SIL27) and 1 as $L b$. plantarum (UFLA SIL35). Lactobacillus plantarum is a facultative heterofermentative bacterium, which usually ferments 1 molecule of glucose into 2 molecules of lactic acid via the energetically homofermentative Embden-Meyerhof pathway. However, Lb. plantarum can also ferment pentose into lactic acid, $\mathrm{CO}_{2}$, and acetic acid via a heterofermentative pathway when glucose is lacking (Holzer et al., 2003). Lactobacillus brevis is an obligate heterofermentative bacterium, which means it lacks the aldolase enzyme and therefore always produces other metabolites, such as ethanol and acetic acid or 1,2-propanediol, in addition to lactic acid (Axelsson, 2004). Thus, it is expected that obligate heterofermentative strains produce more acetic acid than facultative heterofermentative strains.

The strains that produced propionic acid more efficiently were identified as $L b$. plantarum (UFLA SIL41, UFLA SIL42, and UFLA SIL46) and Lb. hilgardii (UFLA SIL51 and UFLA SIL52). Lactobacillus plantarum is commonly used as a silage inoculant, but there are no reports of $L b$. hilgardii being used for this purpose. Lactobacillus hilgardii has been found during vinification and wine storage (Sohier et al., 1999; Mtshali 
et al., 2010), in sugary kefir grains (Leroi and Pidoux, 1993), and during natural ricotta Forte cheese fermentation (Baruzzi et al., 2000). Heinl et al. (2012) found that the metabolism of $L b$. hilgardii is similar to that of $L b$. buchneri, with both species showing an ability to degrade lactic acid and form acetic acid and 1,2-propanediol under anaerobic conditions (Oude Elferink et al., 2001). In the present study, the strains identified as Lb. hilgardii (UFLA SIL51 and UFLA SIL52) produced more propionic acid than the other strains, but the concentrations of this metabolite only reached 0.23 and $0.46 \mathrm{~g} / \mathrm{L}$, which was much less than the lactic (3.16 and $3.37 \mathrm{~g} / \mathrm{L})$ and acetic $(3.60$ and $3.79 \mathrm{~g} / \mathrm{L}$ ) acid concentrations produced by UFLA SIL51 and UFLA SIL52, respectively. The concentrations of 1,2-propanediol in the sugar cane broth fermented by UFLA SIL51 and UFLA SIL52 were also very low. However, the ability of these strains to convert 1,2-propanediol into propionic acid is unknown, similar to that of $L b$. diolivorans.

The chemical composition of the fresh sugar cane and sugar cane silage found in this study was only slightly different from that reported in the literature. The DM and NDF contents of the silages ranged from 253.6 to $264.8 \mathrm{~g} / \mathrm{kg}$, and 568.7 to $682.3 \mathrm{~g} / \mathrm{kg}$, respectively. These values are similar to those found in the literature (Schmidt et al., 2007; Ávila et al., 2009; Carvalho et al., 2012). In most studies that have assessed the fermentation of sugar cane for ensilage (Alli et al., 1982; Pedroso et al., 2008; Ávila et al., 2009), lower DM and higher NDF contents were found in the silage compared with the fresh forage. The increase in the fibrous fraction and decrease in DM content in the silage most likely occurred due to the metabolism of soluble carbohydrates during the sugar fermentation and ethanol synthesis by yeast. Due to these processes, high DM losses occurred in the silage.

In the present study, an increase in the fibrous fraction and decrease in DM content occurred because the same strains that reduced DM losses caused an increase in the DM content and decrease in NDF content of the silage. This effect may have been caused by the dominance of the strains inoculated during the silage process, which could inhibit both the facultative aerobic microorganisms that can grow in the beginning of the process, such as enterobacteria, and other microorganisms that can survive throughout fermentation, such as yeast. Among the silages with the lowest DM losses, only those inoculated with UFLA SIL51 and UFLA SIL52 had larger populations of LAB, which was similar to the control. Thus, the total LAB count alone is not sufficient to characterize the type of fermentation and the quality of the silage. The identification of species or strains present in the silage is more important than the total LAB counts because, as observed in the present study, the metabolism of strains of the same species may vary throughout fermentation.

Among the undesired microorganisms responsible for fermentation losses, only the numbers of yeast and filamentous fungi were assessed. The number of filamentous fungi was $<2 \log \mathrm{cfu} / \mathrm{g}$. This result was also found in other studies on sugar cane silages (Ávila et al., 2009). The silage that exhibited lower losses of DM was also characterized by a smaller yeast population. However, silage such as our control showed greater losses of DM and lower yeast populations. Once again, it is clear that total yeast count alone is not a good indicator of silase quality.

To characterize the silage and, consequently the action of the inoculants, many characteristics of the silage should be assessed. The silage with the lowest loss of DM had a lower ethanol concentration than silages with higher DM losses. The strains that resulted in the greatest loss of DM presented the highest amount of lactic acid. In this silage, homofermentative strains may have been dominant.

The silage inoculated with the UFLA SIL51 and UFLA SIL52 strains had lower concentrations of ethanol than the silage inoculated with other strains (Table 5 ). However, the yeast population was similar to that found in the control silage. Ávila et al. (2010a) identified yeast species during sugar cane silage and reported that different yeasts species had different abilities to produce ethanol. In the current study, the yeast species were not identified. Thus, despite the similarities between the yeast populations in silage inoculated with UFLA SIL51 and UFLA SIL52 strains and the control silage, they can be variable, resulting in the production of a different amount of ethanol. Similar results were also found by Carvalho et al. (2012).

The silage inoculated with UFLA SIL51 and UFLA SIL52 showed higher concentrations of acetic acid and 1,2-propanediol compared with the silage inoculated with the other LAB strains. Acetic acid is a weak acid in an environment with a $\mathrm{pH}$ lower than its acid dissociation constant $\left(\mathrm{p} K_{\mathrm{a}} ; 4.73\right)$. At this $\mathrm{pH}$, the acid remains in its undissociated form and enters the cell of the microorganism. Once inside the cell, the acid is dissociated and releases $\mathrm{H}^{+}$ions, which reduces the intracellular $\mathrm{pH}$. To increase the $\mathrm{pH}$ again, the microorganism must expel the $\mathrm{H}^{+}$ions by an active transport process, which requires energy, thus delaying growth and potentially causing the death of the cell (Davidson, 2007). Other studies have reported that silages with higher concentrations of acetic acid have lower yeast counts (Driehuis et al., 2001; Filya et al., 2006).

1,2-Propanediol can be produced by some LAB, such as $L b$. buchneri and $L b$. brevis, from lactic acid. However, in the present study, the amounts of 1,2-pro- 
panediol were much higher in the silage inoculated with Lb. hilgardii, which has a similar metabolism to that of Lb. buchneri and Lb. brevis. Thus, Lb. hilgardii might also produce 1,2-propanediol from lactic acid. It was not clear whether $L b$. diolivorans converted the 1,2-propanediol into propionic acid because the propionic acid levels were variable and showed no correlation with those of 1,2-propanediol in the current study. Somehow, these microorganisms were the main contributors to the quality of the sugar cane fermentation, which seems to be determined by the production of acetic acid.

Concentrations of butyric acid were variable and were lower than $5 \mathrm{~g} / \mathrm{kg}$ of DM for all silages. Sugar cane silage generally has a lower butyric acid concentrations because of its low $\mathrm{pH}$ value, which is usually below 3.5 (Amaral et al., 2009; Zopollato et al., 2009). The effect of inoculants containing different strains on the butyric acid concentration of the silage varied, but silage inoculated with UFLA SIL19, UFLA SIL42, UFLA SIL46, UFLA SIL51, or UFLA SIL52 had lower concentrations of butyric acid than silages inoculated with the other strains. Carvalho et al. (2012) found a reduction in the butyric acid concentration in sugar cane silage from 7.7 to $5.0 \mathrm{~g} / \mathrm{kg}$ within $60 \mathrm{~d}$ of fermentation. However, after $170 \mathrm{~d}$ of fermentation, the butyric acid concentration in the silage inoculated with $L b$. buchneri increased from 4.0 to $12.0 \mathrm{~g} / \mathrm{kg}$.

Data regarding the aerobic stability of silage, which was measured by temperature fluctuations, showed similarities in the silages inoculated with different LAB strains. The lack of a significant effect can be explained by the high variation in the results. In the present study, the time over which silage remained stable was less (24 h) than that found by Ávila et al. (2009; 33 and 60h).

The strains that provided better silage characteristics, such as a smaller yeast populations, lower ethanol content, and less DM loss, were selected based on their high production of acetic or propionic acids. These data confirmed that facultative heterofermentative strains are not good candidates as inoculants for sugar cane silage and may even decrease silage quality by increasing DM losses throughout the fermentative process. The strains that produced acetic or propionic acids in addition to lactic acid were the most suitable for this type of silage because acetic and propionic acids are more effective in inhibiting yeast, which causes the greatest problems during sugar cane ensilage. Strains UFLA SIL51 and UFLA SIL52 were the most promising in reducing DM losses, as well as being the strains that resulted in a smaller yeast populations, lesser ethanol production, a greater population of LAB, and lower concentration of butyric acid. The greater production of acetic acid and 1,2-propanediol may have inhibited the metabolism of yeast during the anaerobic fermenta- tion of the silage, resulting in lower DM losses. This effect, however, was not observed after the opening of the silos. Reduction of DM loss is the main objective when LAB inoculants are used in silage, because losses during anaerobic fermentation are greater than those during the aerobic phase of the sugar cane silage. Therefore, Lb. hilgardii was suitable for use in sugar cane silage and should be evaluated in other cultures.

\section{CONCLUSIONS}

Preselection of bacterial strains for sugar cane silage in the laboratory is useful when a large number of microorganisms must be assessed. In general, obligatory heterofermentative strains showed better results than facultative heterofermentative strains, in terms of DM loss, in the anaerobic phase of silage fermentation. The strains UFLA SIL51 and UFLA SIL52, identified as $L b$. hilgardii, were the most promising.

\section{ACKNOWLEDGMENTS}

The authors thank Conselho Nacional de Desenvolvimento Científico e Tecnológico do Brasil (CNPQ), Fundação de Amparo a Pesquisa de Minas Gerais (FAPEMIG, Brazil), Coordenação de Aperfeiçoamento de Pessoal de Nível Superior(CAPES, Brazil), and Lallemand Animal Nutrition SAS (Milwaukee, WI) for financial support and scholarship.

\section{REFERENCES}

Alli, I., B. E. Baker, and G. Garcia. 1982. Studies on the fermentation of chopped sugar cane. Anim. Feed Sci. Technol. 7:411-417.

Amaral, R. C., A. V. Pires, I. Susin, L. G. Nussio, C. Q. Mendes, and A. L. Gastaldello Junior. 2009. Cana-de-açúcar ensilada com ou sem aditivos químicos: Fermentação e composição química. Braz. J. Anim. Sci. 38:1413-1421.

AOAC (Association of Official Analytical Chemists). 1990. Official Methods of Analysis. 15th ed. Association of Official Analytical Chemists, Washington, DC.

Ávila, C. L. S., C. E. C. Bravo-Martins, and R. F. Schwan. 2010a. Identification and characterization of yeasts in sugar cane. J. Appl. Microbiol. 109:1677-1686.

Ávila, C. L. S., J. C. Pinto, H. C. P. Figueiredo, and R. F. Schwan. 2009. Effects of an indigenous and a commercial Lactobacillus buchneri strain on quality of sugar cane silage. Grass Forage Sci. 64:384-394.

Ávila, C. L. S., R. F. Schwan, J. C. Pinto, and B. F. Carvalho. 2011. Potential use of native microorganisms strains of forage for silage production. Pages 25-44 in II Symposium on Forage Quality and Conservation. M. Zopollatto, L. L. P. Daniel, L. G. Nussio and A. Sá Neto, ed. Fundação de Estudos Agrários Luiz de Queiroz (FEALQ), Piracicaba, Brazil.

Ávila, C. L. S., A. R. Valeriano, J. C. Pinto, H. C. P. F. Figueiredo, A. V. Rezende, and R. F. Schwan. 2010b. Chemical and microbiological characteristics of sugar cane silages treated with microbial inoculants. Braz. J. Anim. Sci. 39:25-32.

Axelsson, L. 2004. Lactic acid bacteria: Classification and physiology. Pages 1-63 in Lactic Acid Bacteria. S. Salminen, and A. Von Wright, ed. Marcel Dekker, New York, NY. 
Baruzzi, F., M. Morea, A. Matarante, and P. S. Cocconcelli. 2000. Changes in the Lactobacillus community during Ricotta Forte cheese natural fermentation. J. Appl. Microbiol. 89:807-814.

Brereton, R. G. 2000. Introduction to multivariate calibration in analytical chemistry. Analysis 125:2125-2154.

Cai, Y., Y. Benno, M. Ogawa, and S. Kumai. 1999. Effect of applying lactic acid bacteria isolated from forage crops on fermentation characteristics and aerobic deterioration of silage. J. Dairy Sci. $82: 520-526$.

Carvalho, B. F., C. L. S. Ávila, J. C. Pinto, M. N. Pereira, and R. F. Schwan. 2012. Effects of propionic acid and Lactobacillus buchneri (UFLA SIL 72) addition on fermentative and microbiological characteristics of sugar cane silage treated with or without calcium oxide. Grass Forage Sci. 67:462-471. http://dx.doi.org/10.1111/ j.1365-2494.2012.00863.x.

Daeschel, M. A., R. E. Andersson, and H. P. Fleming. 1987. Microbial ecology of fermenting plant materials. FEMS Microbiol. Rev. 46:357-367.

Davidson, P. M. 2007. Chemical preservatives and natural antimicrobial compounds. Pages 713-746 in Food Microbiology: Fundamentals and Frontiers. M. P. Doyle, L. R. Beuchat, and T. J. Monteville, ed. Am. Soc. Microbiol., Washington, DC.

Devereux, R., and S. S. Wilkinson. 2004. Amplification of ribosomal RNA sequences. Pages 509-522 in Molecular Microbial Ecology Manual. 2nd ed. G. A. Kowalchuk, F. J. de Brujin, I. M. Head, A. D. L. Akkermans, and J. D. van Elsas, ed. Kluwer Academic, Dordrecht, the Netherlands.

Driehuis, F., S. J. W. H. Oude-Elferink, and P. G. Van Wikselaar. 2001. Fermentation characteristics and aerobic stability of grass silage inoculated with Lactobacillus buchneri, with or without homofermentative lactic acid bacteria. Grass Forage Sci. 56:330-343.

Dubois, M., K. A. Gilles, J. K. Hamilton, P. A. Rebers, and F. Smith. 1956. Colorimetric method for determination of sugars and related substances. Anal. Chem. 28:350-356.

Filya, I. 2003. The effect of Lactobacillus buchneri, with or without homofermentative lactic-acid bacteria, on the fermentation, aerobic stability and ruminal degradability of wheat, sorghum and maize silages. J. Appl. Microbiol. 95:1080-1086.

Filya, I., E. Sucu, and A. Karabulut. 2006. The effects of Propionibacterium acidipropionici and Lactobacillus plantarum, applied at ensiling, on the fermentation and aerobic stability of low dry matter corn and sorghum silages. J. Ind. Microbiol. Biotechnol. 33:353-358.

Hammes, W. P., and C. Hertel. 2003. The genera Lactobacillus and Carnobacterium. Pages 320-403 in The Prokaryotes, an Evolving Electronic Resource for the Microbiological Community. M. Dworkin, S. Falkow, E. Rosenberg, K.-H. Schleifer, and E. Stackebrandt, ed. Springer-Verlag, New York, NY.

Heinl, S., D. Wibberg, F. Eikmeyer, R. Szczepanowski, J. Blom, B. Linke, A. Goesmann, R. Grabherr, H. Schwab, A. Pühler, and A. Schlüter. 2012. Insights into the completely annotated genome of Lactobacillus buchneri CD034, a strain isolated from stable grass silage. J. Biotechnol. 161:153-166.

Holden, L. A. 1999. Comparison of methods of in vitro dry matter digestibility for ten feeds. J. Dairy Sci. 82:1791-1794.

Holt, J. G., N. R. Krieg, and P. H. A. Sneath. 1994. Bergey's Manual of Determinative Bacteriology. 9th ed. Williams and Wilkins, Baltimore, MD.

Holzer, M., E. H. Mayrhuber, H. Danner, and R. Braun. 2003. The role of Lactobacillus buchneri in forage preservation. Trends Biotechnol. 21:282-287.

Kandler, O. 1983. Carbohydrate metabolism in the lactic acid bacteria. Antonie van Leeuwenhoek 49:209-224.
Kandler, O., and N. Weiss. 1986. Regular, non-sporing Gram-positive rods. Pages 1208-1234 in Bergey's Manual of Systematic Bacteriology. 2nd ed. P. H. A. Sneath, N. Mair, M. E. Sharpe, and J. G. Holt, ed. Williams and Wilkins, Baltimore, MD.

Kleinschmit, D. H., and L. Kung. 2006. A meta-analysis of the effects of Lactobacillus buchneri on the fermentation and aerobic stability of corn and grass and small-grain silages. J. Dairy Sci. 89:4005-4013.

Krooneman, J., F. A. C. Faber, O. Alderkamp, S. J. H. W. OudeElferink, F. Driehuis, I. Cleenwerck, J. Swings, J. C. Gottschal, and M. Vancanneyt. 2002. Lactobacillus diolivorans sp. nov., a 1,2-propanediol-degrading bacterium isolated from aerobically stable maize silage. Int. J. Syst. Evol. Microbiol. 52:639-646.

Kung, L., Jr., and R. W. Stanley. 1982. Effect of stage of maturity on the nutritive value of whole-plant sugar cane preserved as silage. J. Anim. Sci. 54:689-696.

Leroi, F., and M. Pidoux. 1993. Characterization of interactions between Lactobacillus hilgardii and Saccharomyces florentinus isolated from sugary kefir grains. J. Appl. Microbiol. 74:54-60.

McDonald, P., A. R. Henderson, and S. J. E. Heron. 1991. The Biochemistry of Silage. 2nd ed. Chalcombe Publications, Lincoln, UK.

Moon, N. J. 1983. Inhibition of the growth of acid tolerant yeasts by acetate, lactate and propionate and their synergistic mixtures. J. Appl. Bacteriol. 55:454-460.

Mtshali, P. S., B. Divol, P. Van Rensburg, and M. du Toit. 2010. Genetic screening of wine related enzymes in Lactobacillus species isolated from South African wines. J. Appl. Microbiol. 108:13891397.

Muck, R. E. 2008. Advances in inoculants for silage. Pages 221-232 in Proc. 4th Symp. Strategic Management of Pasture and 2nd Int. Symp. Anim. Prod. Under Grazing, Viçosa, MG, Brazil. O. G. Pereira, J. A. Obeid, D. M. Fonseca, and D. Nascimento Júnior, ed. UFV Press, Viçosa, Brazil.

O'Kiely, P. 1993. Influence of a partially-neutralised blend of aliphatic organic acids on fermentation, effluent production and aerobic stability of autumn-grass silage. Ir. J. Agric. Food Res. 32:13-26.

Oude Elferink, S. J. W. H., J. Krooneman, J. A. Gottschal, S. F. Spoelstra, and F. Faber. 2001. Anaerobic conversion of lactic acid to acetic acid and 1,2-propanediol by Lactobacillus buchneri. Appl. Environ. Microbiol. 67:125-132.

Pedroso, A. F., L. G. Nussio, D. R. S. Loures, S. F. Paziani, J. R. Ribeiro, L. J. Mari, M. Zopollatto, and P. Schmidt. 2008. Fermentation, losses, and aerobic stability of sugar cane treated with chemical or bacterial additives. Scientia Agricola 65:589-594.

Roth, A. P. T., R. A. Reis, G. R. Siqueira, M. T. P. Roth, F. D. Rezende, and R. R. Monteiro. 2010. Sugar cane silage production treated with additives at different times post burning. R. Bras. Zootec. 39:88-96.

Saarisalo, E., E. A. Skytta, T. Haikara, T. Jalava, and S. Jaakkola. 2007. Screening and selection of lactic acid bacteria strains suitable for ensiling grass. J. Appl. Microbiol. 102:327-336.

Schmidt, P., L. J. Mari, L. G. Nussio, A. de Faria Pedroso, S. de Fátima Paziani, and F. S. Wechsler. 2007. Aditivos químicos e biológicos na ensilagem de cana-de-açúcar. 1. Composição química das silagens, ingestão, digestibilidade e comportamento ingestivo. Braz. J. Anim. Sci. 36:1666-1675.

Sohier, D., J. Coulon, and A. Lonvaud-Funel. 1999. Molecular identification of Lactobacillus hilgardii and genetic relatedness with Lactobacillus brevis. Int. J. Syst. Bacteriol. 49:1075-1081.

Zopollatto, M., J. L. P. Daniel, and L. G. Nussio. 2009. Aditivos microbiológicos em silagens no Brasil: Revisão dos aspectos da ensilagem e do desempenho de animais. Braz. J. Anim. Sci. 38:170-189. 